\title{
DR. JOHNSON AS A BIBLIOGRAPHER
}

D the generosity of Lady Wernher the British Museum acquired in 1916 three letters ${ }^{2}$ of Dr. Johnson relating to the collecting of books for the King's Library.

- The third and most important of these is the famous one addressed to Mr., afterwards Sir, Frederick Augusta Barnard, the librarian, dated 28 May 1768 , which was first published by the latter in the Introduction to his Bibliothecae Regiae Catalogus, vol. i, 1820, p. iii, after he had refused Boswell permission to print it. ${ }^{2}$ It was subsequently repeated in the Report of the Committee on Papers relating to the Royal Library, \&c., 1823 , P. ii ; in the Gentleman's Magazine, 1823, part i, p. 347 ; in the Report from the Select Committee on the condition, management, and affairs of the British Museum, 1835, p. 386 ; in Boswell's Life of Fobnson, ed. Croker, 1848 , p. 196 ; and in Dr. G. Birkbeck Hill's edition of Johnson's Letters, 1892, vol. i, p. 142. All these reprints, it should be noted, were made from Barnard's Introduction and not from the original letter, which remained in the family of the recipient until it was presented, with the two others, by his greatgrandson, Major-General W. Osborne Barnard, to the Red Cross sale at Christie's in 19r6. It is now possible for the first time to correct a number of mistakes in the printed editions, and to supply a passage hitherto omitted, in which the writer gives some rather striking bibliographical information. It is probably on this account that it was withheld by Barnard, who no doubt found it as difficult of explanation as it appears nowadays. The passage in question comes inme-

1 Now Add. MS. 39303 .

2 Boswell's Life of Yobnson, ed. G. B. Hill, 1887, vol. ii, p. 33 note 4. 
diately after the sentence "These discoveries are sufficient to 'raise hope and instigate inquiry', which will be found on p. 147, 11. 7-8, of Dr. G. B. Hill's edition of the Letters, vol. i, and is as follows:

'One hint more may deserve to be added, though it is ' not very likely that you will have any opportunity of turning 'it to profit. It is recorded by those that have. with the 'greatest diligence examined the first essays of typography, 'and particularly by Naudaeus the Librarian of Cardinal

'Mazarine, that the stamp or insigne by which Fust marked ' his editions were Horns, and I have read an advertisement of "a Book offered to sale in Holland that was so stamped. 'For these horns I have looked to no purpose in the books "printed by Fust which are commonly known, yet since it 'casnot be doubted but that there are yet in the world books 'so marked I believe you may consider them, if ever you "should find them, as printed before 1458 , for those printed ' after that year I think, always want the stamp.'

The following is a list of corrections, made with reference to Dr. Hill's edition of the letters, as being the most generally accessible text :

Vol. i, p. I43, I. 8. 'a wantonness' ... Delete' a'.

1. 26. 'in England' ... Delete ' in'.

p. 144, 1. 2. 'in its native soil '... For 'in 'read 'on'.

1. 12. For 'influence' read 'importance'.

1. 26. For 'Graevius' read 'Greevius'.

1. 27. For 'discern' read 'discover'.

p. I45, 1. I. For 'In every place' read 'Try every place,'

1. 6. For 'connected ' read' collected'. (N.B. Rightly printed by Barnard, and in the Committee Reports, etc., but wrong in Croker's ed. of Boswell, $7848, p$. 796$)$.

1. 15. For 'books' read 'loads'. 
11. 18-r9. For 'prevails' read ' prevail'.

1. 20. The word 'Italy' is actually omitted in the $M S$.

p. 146, 1. I2. For 'proportioned' read 'proportionate'.

1. 20. For 'search' read 'searches'.

1. 24. For ' 1457 ' (a kindly correction) read ' 1458 '.

1. 27. For 'is' read 'be'.

1. 28. For ' 1457 ' read ' 1458 '; for ' nineteen' read "eighteen'.

p. 147, 1.8. After 'inquiry' insert passage printed above.

I. Io. For ' edition' read ' editions'.

Eric G. Millar. 